\title{
Madame de La Fayette, La princesse de Montpensier
}

\section{Daniela Dalla Valle}

\section{(2) OpenEdition \\ 10 Journals}

\section{Edizione digitale}

URL: http://journals.openedition.org/studifrancesi/4041

DOI: 10.4000/studifrancesi.4041

ISSN: 2421-5856

\section{Editore}

Rosenberg \& Sellier

\section{Edizione cartacea}

Data di pubblicazione: 1 juillet 2012

Paginazione: 314

ISSN: 0039-2944

\section{Notizia bibliografica digitale}

Daniela Dalla Valle, «Madame de La Fayette, La princesse de Montpensier», Studi Francesi [Online], 167 (LVI | II) | 2012, online dal 30 novembre 2015, consultato il 10 janvier 2021. URL: http:// journals.openedition.org/studifrancesi/4041 ; DOI: https://doi.org/10.4000/studifrancesi.4041

Questo documento è stato generato automaticamente il 10 janvier 2021.

\section{(c) $($ ) $(9)$}

Studi Francesi è distribuita con Licenza Creative Commons Attribuzione - Non commerciale - Non opere derivate 4.0 Internazionale. 


\title{
Madame de La Fayette, La princesse de Montpensier
}

\author{
Daniela Dalla Valle
}

\section{NOTIZIA}

MADAME DE LA FAYETTE, La princesse de Montpensier, Introduzione e traduzione di Federico CORRADI, Roma, Portaparole, 2011, «Maudit», pp. 69+68.

1 Nella bella collana diretta da Elisabetta Sibilio, Federico Corradi pubblica la sua traduzione della nouvelle di Madame de La Fayette, preceduta da un'introduzione corposa e annotata e da una Nota al testo. La stessa nouvelle, con la stessa introduzione e la stessa nota al testo, è pubblicata in francese nello stesso volume, capovolto e partendo dall'ultima pagina.

2 L'introduzione, anche se ridotta a una quindicina di pagine, è estremamente pregevole e attenta ai testi recenti sulla stessa novella e sulla narrativa francese del Seicento. L'evocazione dell'ambiente in cui il testo s'inserisce emerge con chiarezza dalle pagine dell'A. Il testo di Madame de La Fayette è stato ripreso da quello stabilito da Micheline Cuénin (1979), mentre la traduzione - che segue quella di Gesualdo Bufalino e Paola Masino del 1980 -sembra averne tratto alcuni spunti felici. È comunque molto gradevole, molto precisa nella ripresa di alcuni termini particolari, sia pure all'interno di una fedeltà, che può essere verificata e puntualizzata dal possibile confronto con il testo stesso. 